\title{
Editorial
}

\section{Design da informação como enfoque e instrumento para aprendizado}

O design da informação tem tradição no tratamento e organização da informação complexa que em si implica no conhecimento de técnicas, modelos, ferramentas e teorias para produzir um artefato capaz de promover a assimilação dessa informação pelo usuário. Nesta primeira edição do volume 11 da InfoDesign verifica-se a continuidade da tendência do volume anterior em centrar o design nas pessoas. Além disso, essas pessoas assumem seu papel de aprendiz e as teorias de aprendizagem, do comportamento humano e figuras de linguagem sofrem uma releitura e influenciam o tratamento e organização da informação.

Em "Tecnologias no aprendizado da Anatomia Humana: possíveis contribuições para o ensino da medicina" Trotta e Spinillo relacionam a maneira como os conteúdos são apresentados por uma tecnologia e o aprendizado da anatomia humana. As autoras concluem que o modo de apresentação do conteúdo, a escolha da tecnologia, o quanto e o como vai se disponibilizar a informação são fatores decisivos na relação entre aprendizado de conteúdo e tecnologia. Além disso, o usuário deve ser considerado, principalmente em relação às suas limitações, às suas habilidades, e às suas experiências.

A tecnologia também é abordada por Alves e Battaiola, através das aplicações de animação. Em seu artigo "Design Centrado no Usuário e concepções pedagógicas como guia para o desenvolvimento da animação educacional" os autores buscam na literatura indicações sobre o tratamento da animação centrada no usuário e interpretam este usuário como agente ativo capaz de estruturar seus próprios conhecimentos. De acordo com as conclusões de Alves e Battaiola, o artigo reúne alguns modelos sobre design centrado no usuário e sobre as teorias construtivistas, sendo que estes modelos e teorias poderiam servir como base para a criação de animações que promovam o aprendizado.

Continuando com o objetivo de estruturar a informação com o intuito de contribuir para o processo de ensino-aprendizagem, Lapolli, Vanzin e Ulbricht investigam, em "Organização da informação em narrativas infográficas na web voltadas para o processo de ensinoaprendizagem" as narrativas infográficas na web. Este artigo identifica, na literatura, informações sobre como as metáforas visuais, elementos dinâmicos, integração de recursos, obtenção das informações, a organização e a estruturação dessas informações podem gerar infográficos que promovam a aprendizagem. Os infográficos também são os objetos de interesse de Meürer, Blum e Fronza, que descrevem 
em "Recomendações sobre design informacional aplicado em motion graphics" as diferenças na percepção de informações estáticas em comparação às animadas.

A aquisição de conhecimento também é foco da investigação realizada por Freitas, Waechter e Coutinho, e relatada no artigo "Prevenção às DST/Aids: design da informação para promoção da saúde". Porém, neste caso, os autores trabalham com um público de interesse diversificado. Além disto, o artigo verifica se a interpretação das mensagens em materiais impressos com a temática de prevenção às DST/Aids instiga a promoção de comportamentos saudáveis. Os autores identificam a existência de polissemias pictóricas em vários dos artefatos analisados, porém sem o devido tratamento de seus elementos quanto aos aspectos sintáticos e semânticos. Por fim, como salientado nos artigos anteriores, o usuário precisa ser considerado, e os autores reforçam as questões culturais.

O usuário também é o foco da análise da interface feita por Lindner, Ulbricht e Palazzo em seu artigo "Análise da interface padrão do Oxwall como plataforma de rede social”. Para esta análise os autores utilizaram o framework Reader-to-Leader o qual considera aspectos de usabilidade e sociabilidade para promover a participação.

Os artigos seguintes ampliam o escopo temático deste número da InfoDesign, enfocando a informação na perspectiva do design. Em "Design de informação em interfaces digitais: origens, definições e fundamentos" Quintão e Triska buscam delinear o design de informação em interfaces digitais através dos trabalhos de Beck e Neurath, e resgatam alguns dos conceitos e fundamentos. Em "Uso de mapas semânticos no processo de naming - uma abordagem estratégica em um estudo de caso aplicado" Refatti, Goulart, Stein e Merino exploram mapas e painéis semânticos no processo de naming.

Assim, esta edição da InfoDesign apresenta artigos oriundos de pesquisas realizadas no Brasil referentes ao aprendizado de conteúdos, e a apresentação gráfica da informação - quer em interfaces digitais ou analógicas- que possam subsidiar processos e tomadas de decisão de designers. A diversidade de temas e os enfoques dos artigos, todavia, se entrelaçam nos vieses do design da informação, oferecendo uma perspectiva ampla da área aos leitores.

Boa leitura!

Dra. Luciane Maria Fadel

Co-editora da InfoDesign 